\title{
Comparison of executive compensation practices at Nordic and US markets: a mini-review article based on empirical evidence
}

\author{
Ummeh Habiba Faria Benteh Rahman
}

Department of International Business, Faculty of Economics and Management, Norwegian University of Science and Technology, Norway

Correspondence author email: rahmanhabiba26@gmail.com

\begin{abstract}
This paper examines the compensation package of the CEO of both the Nordic and US markets and their roles in the organization. The paper contains the comparison between the compensation package of Nordic and US CEOs along with the harmony of the determinants. The work pattern and compensation are different in these two markets, certainly. It has been a big influence in the organization or working places to provide the most desired efforts on the particular or assigned responsibilities. This study is based on a systematic review of literatures, empirical evidences and surveys extracted from 23 articles of the previous studies on the compensation packages of CEO of both Nordic and US markets. The paper will be discussing about the chief executive body in the organization, the compensation design along with their compensation package system, discussing about the theories and determinants' differences of their compensation practices and how this package is designed in both the Nordic and US markets. The difference between these two markets will be elaborately discussed and following by the author's own discussion. The paper will end by providing a valid conclusion about the whole study.
\end{abstract}

Keywords: Compensation practices, Remuneration package, Pay structure determinants, US pay practices, Nordic pay practices

JEL classification: M1, M48, M51, M52

\section{INTRODUCTION}

Chief Executive Officer or CEO is mostly, the highest ranked position in a company and has more or less a very significant influence on the company's outcomes. CEO is a corporate leader who influences the effectiveness of the organization to the stakeholders. Organizational reputation is affected by this employee vastly (Men, 2012). This important person gets compensated according to the particular company's authorized policy. The compensation package of Nordic CEO has been compared by the compensation package of the US CEO's in this study. US CEOs are paid high rather than the CEOs of Nordic counties. This has been due to the corporate governance and the board committee of the organizations (Conyon \& He, 2004).

CEO compensation package is comparatively lower in the Nordic countries than US markets (Randøy \& Nielsen, 2002). Though according to Scandinavian companies are moving close enough to Anglo-American companies' pay scale for the CEO certainly, the package system has differences based on the corporate governance and CEO compensation includes both the monetary and non-monetary major components 
(Thomsen \& Conyon, 2012). In a certain year, CEO of top Nordic company earned 8.9 million SEK on the other hand, CEO of top US company received 58.9 million USD (Randøy \& Nielsen, 2002). The evolving share of market based factors or transnational mergers and acquisitions or growth of MNCs or any other provocation of market based factors make the compensation packages different in these two markets (Thomas 2008).

The board has to be fair enough for the payment of the Nordic CEOs as their responsibilities matter a lot in the companies. On the other hand, US CEOs "monopoly game" of their pay system has to be diminished or must be equivalent to EU or Nordic CEOs.

The purpose of this study is to provide a systematic empirical evidences of the difference between US and Nordic CEO Compensation practices. From the previous studies, author has collected the determinants which gives clear picture of the payment practices for the executive bodies in both US and in Nordic markets. This paper further aims to provide a comprehensive understanding of determinants differences in the applicability of preparing the payment design of both of these market's chief bodies. Specifically, this paper will focus on two major questions, and these are: (1) Does USA focus paying to CEO by not focusing on the performance? and (2) Do Nordic CEOs need more monetary motivation in the organization? The following section describes the main concepts compensation practices and design. The study also provides pay practices for both US and Nordic markets. At the end of this study, discussions by the author has put a clear picture of the differences between two markets.

\section{METHODOLOGY}

A systematic review has been done according to the guidelines suggested by (Tranfield, Denyer, Smart, 2003) as: a) building scope of the study, b) identification of research, c) discussion of the literatures, d) study quality assessment, e) data monitoring.

This paper has been stated by designing keywords and by processing following the questions of interest. The inclusion and exclusion criteria have been decided. The discussions of the literature were done from the studies which have been published online. All the topics were collected from different scholars' write up, but unfortunately, many publications were not up to the standard level and very generic. To retrieve the relevant articles, the author has used keywords, i.e. "compensation management", "Pay practices in USA", "Compensation design", "CEO gets low paid", etc.

The number of articles was then narrowed down. Articles or journals were based on the differences of CEO compensation package between USA and Nordic countries. Out of 35 articles, author have chosen 23 most relevant to the research area. The author has selected these articles because these have clarified the determinants which decide the pay system in USA and Nordic countries and the usage of models of corporate governance.

Though recent articles or journals were not sufficiently available on the sources, there was no limit of the year of publications as the previous studies have the importance as well though there are many new ideas added up with the new or recent papers. Taking into consideration both most recent and most significant literature gives the opportunity to deliver more accurate analysis.

\section{MAIN CONCEPTS COMPENSATION PRACTICES AND DESIGN}

\section{What is compensation practices?}

Compensation practice is the existence of a system which provides adequate and fair remuneration to employees in exchange for the work they have performed (Baker, 
Jensen, Murphy, 1988). There are various ranks in the organization allocated with various descriptions of work or job and according to those, package of compensation is designed. Each organization has their own policy to build that practice (Talley \& Johnsen, 2004). Managerial pay which depends on the performance, minimizes the moral hazard. According to the economics models, the higher the performance, the greater the effort or in other words, employee providing great efforts to produce bigger performances (Baker, Jensen, Murphy, 1988).

Generally, as the work of a CEO is the top most so, his or her payment for the exchange of work is also the highest but executive compensation is controversial in the debate field of the corporate governance (Talley \& Johnsen 2004). After the analyses of some significant literatures, it has been stated robustly that the relation between position and performance is weaker and the actual compensation practice is not therefore, matches with the expected one (Talley \& Johnsen, 2004). A significant negative relationship had been discovered between the performance and the practice of compensation of CEOs in the organizations (Randøy \& Nielsen, 2002).

Overall, over the past thirty years, international compensation practice can be classified into two classifications: practice of American CEO Compensation has been highly controversial because of the vigorous increment and the other classification goes for the Nordic CEO Compensation practice which did not increase proportionately by the passage of time (Thomas, 2008).

\section{Remuneration package design}

From recent years, compensation design effected the efforts of the employees in the organization This design offer opportunities to the changes of organization's strategy (Mahoney 1989). The design of the compensation package includes the base salary, stock ownership and bonus payments. The design is set by the committee or the board members in the company as it was mentioned before. From the research empirical evidences, it has been said that compensation plans indicate or talk about the explicit financial rewards in the form of things i.e. performance-based bonuses or worker's compensation (Baker, Jensen, Murphy, 1988).

The author will be discussing the examples of compensation design below:

Base salary: Base salary is the basic amount of money which a CEO gets in exchange of his or her work and it is generally fixed. The fixed amount of this is based on the size and profit of the company. Additionally CEO might get something very huge or any terrific reward but the basic salary will be always there until he or she gets fired! It is always there. For example if a CEO's total salary is 500,000 Euro or USD then 350,000 Euro or USD will be the basic salary (hypothetical).

Bonus: is the additional amount of money which a CEO gets with the basic salary. It is a monetary reward in exchange of better performance i.e. meeting desired targets or KPI. On the other hand it can be for profit or revenue growth, increase in share price and so on. For example: Let us drag the amount from the above example so, from there, 50,000 Euro or USD will be the bonus amount which makes the total salary $(350,000+50,000)$ Euro or USD $=400,000$ Euro or USD.

Stock ownership: Stock options are provided to link the interest of executive's and shareholders. It is offered to the CEO so that the person takes the organisation as his or her own and performs better. The return from the share is added to the overall salary. It makes the salary healthier and allows the CEO to buy shares of the company. For example: more 50,000 Euro or USD added to 400,000 Euro or USD which makes the salary now 450,000 Euro or USD 
Stock options: this is the option which gives the CEO of a particular company to buy the shares of the company. It gives the executive to obtain more income added to the basic salary. For example: return on investment will be more 50,000 Euro or USD will make the total amount of the CEO's salary which is 500,000 Euro or USD.

\section{DIFFERENCES OF PAY STRUCTURE DETERMINANTS BETWEEN US AND NORDIC CEO COMPENSATION}

The following topic will be discussing about the compensation practices followed by the differences. The result of the evidences suggest that the compensation determinant in US country is based on the firm's structure, size, performance and ownership (Magnan, St-Onge, Thorne, 1995). Market forces mainly decide the executive compensation in USA (Kaplan 2008). In U.S CEO compensation is strongly based on some model for example, according to (Bebchuk \& Fried 2005), US public companies has moved aimlessly from the model of economics which is named as "arm's length contracting". It happened between the board and executives in labor market which is competitive. The three-tier agency model in the U.S where the presence of significant shareholders make the decision of lower CEO payment and on the other hand with higher CEO equity incentives (Conyon \& He 2004).

Firms which have the higher paid compensation committee, there the members are connected with greater CEO compensation and on the other hand, lower incentives (Conyon \& He. 2004). The evidence supports that the board of the committee will be benefitted from the outsider directors more for setting the CEO's yearly compensation service (Mangel \& Singh 1993). CEO compensation in Anglo-American financial market effect the product and service internationalization of the firm (Oxelheim \& Randøy, 2005).

If we look at the Nordic countries then we can see that welfare state model or the Nordic model policies are chosen for the payment of wages/salaries to the CEOs (Gupta, Smith, Verner, 2008). From 5-year pay panel in Denmark, which is one of the Nordic countries, according to the job positions i.e. performance related pay and authority, payment should be determined and not based on the individual pay differentials (Eriksson, 2000). From public listed firms in Sweden, it is shown that despite of the fixed nature, firm's performance and CEO compensation has a positive relation (Oxelheim \& Clarkson, 2015). The relative success of managerial power theory versus agency theory explains CEO compensation having close ties with the chairman compensation in Swedish public listed firms (Oxelheim \& Clarkson, 2015).

In Nordic companies, even in privately held firms, the relationship between payment and performance is week than the Anglo-American companies. It is been studied by (Banghøj, Gabrielsen, Petersen \& Plenbor, 2010) that a strong payment according to the performance is absent even in firms where bonus plans are better designed. In the following section, US and Nordic pay practices will be discussed which have been derived from the determinants.

\section{US pay practices}

Indeed, US CEOs are paid more compared to similar firms situated elsewhere in the world. Much reform is needed in the US executive compensation practices as these are falling in a widespread manner (Core, Guay, Thompson, 2005). USA It is undisputable that US CEOs are paid compared to any other foreign countries and there are four primary components which build up the compensation package and these are: base salary, annual bonus, stock options and long term incentive pay (Thomas, 2008). Critics of corporate governance have stated that US CEOs are neither paid according to 
their performance nor boards monitor actively the compensation design of them in the publicly owned firms (Kaplan, 2008).

Much of the payments of US CEO comes in the form of variable payments. There is a positive relationship between pay and firm size in the US market. CEO turnover and stock performances is closely tied with each other since 1970's (Kaplan 2008). Compensation is higher when foreign sales are higher, and when the foreign firms are cross-listed on U.S. exchanges (Fernandes, Ferreira, Matos \& Murphy, 2009). In the year 1997, 1600 publicly traded American corporations were being surveyed and it was found that 63 percent of CEO income comes from the variable pay i.e. high performance (Thomas, 2008). Over 1990's stock options in USA rose 300 percent that means from 5 percent to 15 percent. However, in the year 2007, "performance-based plans" overtook the stock options in the form of long term incentive plan. US monopoly regarding CEO compensation has the cause and effect in international rules.

A huge amount of stock is held by the individual investors in the US public corporations; therefore, highly diversified portfolio stocks are maintained (Balkin 2008). US CEOs earn $45 \%$ more cash compensation and $190 \%$ more total compensation, this calculation is after considering the size, sector and executive characteristics of other firms. They also receive $1.48 \%$ from any kind of increase in any shareholder's wealth (Conyon \& Murphy, 2000). The managerial influence led the increment in US payments of executive compensation by ignoring the performance in the firms (Bebchuk \& Fried, 2005).

Finally, according to the critics, it has been said that the executive's payment is high as there is no real markets of executives. Therefore, they set their pay level. We can conclude by saying that this is the ownership structure of the firms which allows the US CEOs get well paid than other nationalities' CEOs.

\section{Nordic pay practices}

According to the data, the living cost in Nordic countries are higher than US but still Nordic CEOs are paid little than US CEOs. The most commonly argued about the payment of Nordic CEOs are that their jobs are more demanding which pay them well rather they their position in the company (Oxelheim \& Randøy, 2010). According to the agency theory, linkage between the firm's performance and CEO payment should give mechanism of company success. As CEOs are hired from outside in Norway and Sweden, they have more bargaining power about their salary (Randøy \& Nielsen, 2002). Scandinavian CEOs are paid very low as the foreign owners are mostly from US or UK. Previously it was said in the paper that it is the ownership structure who decides the pay scale of the CEOs.

The ingredients of the CEO payment has been divided into cash, bonus, and long term incentives which goes higher if the company size increases. Pay structure of the Nordic corporations are heavily skewed towards salary rather than variable payment. The long term plans or incentives is 8.4 percent of total pay only (Thomas 2008). Chairman compensation is set after the CEO compensation in Nordic countries so, it has been stated in the empirical evidence that chairman may be inclined to conspire with the CEO in earnings management efforts. This is the expense of monitoring on behalf of investors (Oxelheim \& Clarkson, 2015).

Due to the family controlled ownership, the remuneration is relatively low. Risk metrics study of 2008 has declared that the Nordic CEOs salaries are measured as "industrial workers' salaries" (Gupta, Smith, Verner, 2008). A lower level of CEO compensation makes the shareholders benefitted as it provides higher rate of return to 
them. (Randøy \& Nielsen, 2002), stated that the business has been apparently expended in Nordic countries, despite the CEO compensation is lower in this territory.

\section{DISCUSSION}

According to the articles, the author has referred to, Scandinavia is ruled by the Social Democrat because the he political structure of these countries are supported or guided by the social democracy. These economic and social interventions actually promote or have been promoting the social justice. As we know, the mixed economy basically follows or end to follow capitalistic behaviors therefore, these intervention of Scandic countries provide justice in the framework of liberal democratic policy. Therefore, the payment system here are mostly based on the equity or on the quality of the performances.

Moreover, USA is a pure Capitalistic country as it plays the main difference. The political structure in this country leads to the private ownership mostly. Therefore, the payment system intends to grab attention on profits rather on the quality of performances. Not necessary, it has to be always on the monetary way of payment but also the total price or payment system including stock ownership (mentioned above). US firms should reduce the amount of variable payments to its CEOs i.e. stock plans as it makes them "too rich" (Thomsen \& Conyon, 2012) and it will provoke them to work for self-interest.

However, recently, a potential trend has been observed the merging possibilities or probabilities of the two payment systems. Author's first question, "Does USA focus paying to CEO by not focusing on the performance?" is discussed: Executive compensation is aligned with agency theory and to attract competence but there are pros and cons as well in the stock options and stock options is included in the compensation package. Pros are positive certainly but cons make the performance ratio to fall as the CEO's become more money oriented rather than focusing on the purpose of their power in the workplace.

Executive pay is higher in US than in Europe. CEO drives the magnitude in the firm by holding back the stock (Bebchuk \& Fried, 2003). The problem occurs with the power position of the CEO so, the compensation committee wants it to be transparent always, improvement in pay practices and improvements in boar accountability (Bebchuk \& Fried, 2005). Actually, the package is set or determined by the members of the board of the company but many also think that CEO can lobby over boards and have high payments (Bebchuk \& Fried, 2003). Referencing in the payment system sometimes hinder the ways of recognizing or identifying the proper candidates for the proper roles in the office (especially in the executive levels) which makes a loss in the work hierarchy and harmony of the accountancy/transparency.

Author's second question, "Do Nordic CEOs need more monetary motivation in the organization?" is discussed: though, compensation package is very important for the effective role play in the organization, the divergence between the package of US and Nordic will be even wider at least according to some researchers (Thomas, 2008). However, a market failure may take place if the CEO starts acting opportunistic (Balkin, 2008). Opportunistic behavior can be hidden or ineffective in the short run but in the long run, it may also be the reason of "downsizing", "cost-cutting" and "Golden handshake"

Nordic CEOs have more responsibilities (as it is the highest rank) so, they need more motivation in a monetary way. If the monetary motivation is always being deprived then turnover costs may be way too high in the Nordic markets than expected. On the other hand, brand reputation of the companies in the way of payment scale may have bad tags too. Their variable pays should be increased as well. The author also encourages the 
Nordic market system to organize stock options for the CEOs just like US market. It will increase the security of their jobs and executives will have more bright retirement plans. However, these options must have a valid limitations and well-structured accordingly. This must be declared the board otherwise the opportunistic behaviors can be cultivated deep inside of their minds too as stock options will be making them more rich than they have expected before.

\section{CONCLUSION}

The author wants to conclude by saying that though companies form the similar industry located in different continents have the vast differences in setting the compensation package of the highest ranked person i.e. executives. The top most people of the companies are very precious and they must be prioritized according to their ability and companies' affordability. Employees must be treated as "assets" of the company which will help to provide a matured and desired pay level according to their working responsibilities.

If the companies real assets which are human resources are being taken as granted then certainly these people will be utilizing companies' internet to be shifted on new place! (Looking for other jobs by sitting in the office). The harshest truth is that "payment scale" or the structure of the monetary benefits are the most real cause to hold or attract any type of employees in a company.

\section{REFERENCES}

Baker, G.P., Jensen, M.C. \& Murphy, K.J. (1988). Compensation and incentives: Practice vs. theory. The journal of Finance. 43(3), 593-616.

Balkin, D.B. (2008). Explaining high US CEO pay in a global context: An institutional perspective. In Gomez-Mejia, L. \& Werner, S. (Eds.), Global compensation: Foundations and perspectives. London: Routledge

Banghøj, J.M., Gabrielsen, G., Petersen, C. \& Plenbor, T. (2010). Determinants of executive compensation in privately held firms. Accounting \& Finance. 50(3), 481510.

Bebchuk, L.A. \& Fried, J.M. (2003). Executive compensation as an agency problem. Journal of economic perspectives. 17(3), 71-92.

Bebchuk, L. A. \& Fried, J.M. (2005). Pay without performance: Overview of the issues. Journal of applied corporate finance. 17(4), 8-23.

Conyon, M.J. \& He, L. (2004). Compensation committees and CEO compensation incentives in US entrepreneurial firms. Journal of Management Accounting Research. 16(1), 35-56.

Conyon, M.J. \& Murphy, K.J. (2000). The prince and the pauper? CEO pay in the United States and United Kingdom. The Economic Journal. 110(467), 640-671.

Core, J.E., Guay, W.R. \& Thompson, R.S. (2005). Is US CEO compensation inefficient pay without performance. Mich. L. Rev. 103 (6), 1142 - 1185.

Eriksson, T. (2000). What Determines Managers' Pay?: Evidence from Denmark. Long Range Planning. 33(4,: 544-559.

Fernandes, N., Ferreira, M.A., Matos, P. \& Murphy, K.J. (2009). The pay divide:(Why) are US top executives paid more. Finance Working Paper No.225, University of Southern California.

Gupta, N.D., Smith, N. \& Verner, M. (2008). The impact of Nordic countries' family friendly policies on employment, wages, and children. Review of Economics of the Household. 6(1), 65-89. 
Kaplan, S.N. (2008). Are US CEOs Overpaid? Academy of Management Perspectives. 22(2), 5-20.

Magnan, M.L., St-Onge, S. \& Thorne, L. (1995). A comparative analysis of the determinants of executive compensation between Canadian and US firms. Relations Industrielles/Industrial Relations. 50(2), 297-319.

Mahoney, T.A. (1989). Multiple pay contingencies: Strategic design of compensation. Human Resource Management. 28(3), 337-347.

Mangel, R. \& Singh, H. (1993). Ownership structure, board relationships and CEO compensation in large US corporations. Accounting and Business Research. 23(sup1), 339-350.

Men, L.R. (2012). CEO credibility, perceived organizational reputation, and employee engagement. Public Relations Review. 38(1), 171-173.

Oxelheim, L. \& Clarkson, K. (2015). Cronyism and the determinants of chairman compensation. Journal of business ethics. 131(1), 69-87.

Oxelheim, L. \& Randøy, T. (2005). The Anglo-American financial influence on CEO compensation in non-Anglo-American firms. Journal of International Business Studies. 36(4), 470-483.

Oxelheim, L. \& Randøy, T. (2010). European Corporate Governance Guidelines and CEO Pay-The Case of Norway and Sweden.

Randøy, T. \& Nielsen, J. (2002). Company performance, corporate governance, and CEO compensation in Norway and Sweden. Journal of Management and Governance. 6(1), 57-81.

Talley, E.L. \& Johnsen, G. (2004). Corporate governance, executive compensation and securities litigation. USC Law School, Olin Research Paper_(04-7).

Thomas, R.S. (2008). International executive pay: Current practices and future trends.

Thomsen, S. \& Conyon, M. (2012). Corporate governance: Mechanisms and systems, London: McGraw Hill.

Tranfield, D., Denyer, D. \& Smart, P. (2003). Towards a methodology for developing evidence-informed management knowledge by means of systematic review. British journal of management. 14(3), 207-222. 